\title{
The Analysis of Students and Teachers Readiness on Distance Learning Mathematics in New Normal
}

\author{
Ratnadewi \\ Electrical Engineering Department, Universitas Kristen Maranatha, Indonesia \\ ratnadewi@maranatha.ac.id
}

Article History Received : January $7^{\text {th }} 2021$

Revision : February $11^{\text {th }} 2021$

Publication : March 30th 2021

\begin{abstract}
A sudden pandemic has created a learning system in Indonesia, which is usually done face-to-face, in the New Normal era, online learning is required. This sudden incident turned the wheel of life and learning 180 degrees. This paper discusses the level of readiness of students and teachers in mathematics distance learning. The level of readiness includes ownership of electronic devices, availability of internet signals, costs, support from parents or people around, skills in accessing digital learning applications, learning places, teachers who can teach well, materials, teacher guidance, solutions if they encounter problems, abstinence give up, and be able to understand distance learning material. Data obtained from the results of questionnaires and interviews with students and teachers in Indonesia. The results of the analysis of the data obtained are that students and teachers are in the criteria of being quite ready to be very ready to carry out distance learning. From the results of questionnaires and interviews, both students and teachers prefer a mixture of distance and face-to-face learning, because when it is difficult to understand the learning material, the teacher can explain directly, more able to monitor the condition of students. The weakness of distance learning is that it is constrained by internet signals, no emotional bonds, it is difficult to monitor students' abilities and higher credit costs.
\end{abstract}

Keywords: Distance learning; Student; Teacher.

\section{INTRODUCTION}

In the New normal era of the Covid-19 pandemic, the educational aspect of distance learning began to apply. This is confirmed by the Ministry of Education and Culture circular letter number 15 of 2020 that during the new normal, learning is directed online or offline. This of course requires the readiness of teachers and students in distance learning. The readiness observed in this paper is learning tools, such as computers/laptops, cellphones, internet pulses, skills to operate online applications or social media. This is necessary because before the pandemic learning was carried out face-to-face so that when faced with the necessity of online learning, 
of course the infrastructure would be different. Observations are made in Mathematics which need students' understanding and abstraction abilities. Data obtained through data collection from questionnaires, interviews, and observations.

Research on the direction of education in the future in the form of blended learning due to communication with information technology is growing so that communication is no longer hindered by distance. Based on the consideration of effectiveness, face-to-face and online courses in mixed learning are more attractive to students because the relevance of learning content felt by students is more in line with student interests and needs. Things that support online learning include organization, perceived content relevance, expected value, information and communication, respect and attention to students, creating a learning environment, feedback and performance, and assistance to students to achieve goals (Dziuban et al., 2018) (Idaho Digital Learning, 2014).

Research on science, technology, and mathematics (STEM) project-based learning was conducted by (Han et al., 2014) at Southwestern University. The study was conducted to determine the effect of STEM learning on individual student mathematics performance. Demographic background, ethnicity, and economic status affect the level of student achievement performance. The results of this study suggest that STEM project-based learning in schools is very beneficial for low achieving students and reduces achievement gaps.

The concept of online teaching on masters of wind energy systems in the United States, Canada and Germany is carried out by (Gleim \& Kuhl, 2017). The teaching concept is divided into three types, namely the concept of synchronous learning, asynchronous learning, and a combination of synchronous learning and asynchronous learning. It has been observed that asynchronous online teaching is very popular with students in the United States, synchronous schools are preferred by students in Canada, and synchronous and asynchronous combinations are preferred by students in Germany.State the objective of the research explicitly at the end of the introduction and how your research will meet this objective.

In the New normal era of the Covid-19 pandemic, the educational aspect of distance learning began to apply. This is confirmed by the Ministry of Education and Culture circular letter number 15 of 2020 that during the new normal, learning is directed online or offline. This of course requires the readiness of teachers and students in distance learning. The readiness observed in this paper is learning tools, such as computers/laptops, cellphones, internet pulses, skills to operate online applications or social media. This is necessary because before the pandemic learning was carried out face-to-face so that when faced with the necessity of online learning, of course the infrastructure would be different. Observations are made in Mathematics which need students' understanding and abstraction abilities. Data obtained through data collection from questionnaires, interviews, and observations. 
Research on the direction of education in the future in the form of blended learning due to communication with information technology is growing so that communication is no longer hindered by distance. Based on the consideration of effectiveness, face-to-face and online courses in mixed learning are more attractive to students because the relevance of learning content felt by students is more in line with student interests and needs. Things that support online learning include organization, perceived content relevance, expected value, information and communication, respect and attention to students, creating a learning environment, feedback and performance, and assistance to students to achieve goals (Dziuban et al., 2018) (Idaho Digital Learning, 2014).

Research on science, technology, and mathematics (STEM) project-based learning was conducted by (Han et al., 2014) at Southwestern University. The study was conducted to determine the effect of STEM learning on individual student mathematics performance. Demographic background, ethnicity, and economic status affect the level of student achievement performance. The results of this study suggest that STEM project-based learning in schools is very beneficial for low achieving students and reduces achievement gaps.

The concept of online teaching on masters of wind energy systems in the United States, Canada and Germany is carried out by (Gleim \& Kuhl, 2017). The teaching concept is divided into three types, namely the concept of synchronous learning, asynchronous learning, and a combination of synchronous learning and asynchronous learning. It has been observed that asynchronous online teaching is very popular with students in the United States, synchronous schools are preferred by students in Canada, and synchronous and asynchronous combinations are preferred by students in Germany.

\section{METHOD}

Descriptive research methods with qualitative and quantitative approaches are used in the article here. The research subjects were students who were studying mathematics. The results showed that a positive attitude can be obtained when students learn mathematics (Lijie et al., 2020). The research instrument is a questionnaire that is distributed online and randomly, and interviews in the form of questions and answers from respondents, based on the conditions of distance learning in Indonesia. This study aims to explore information about distance learning readiness from the teacher as the teacher and the students as being taught. The data obtained through a questionnaire were then analyzed using the Miles \& Hebberman model, namely reduction, presentation, verification and conclusion (Miles \& Huberman, 2014).

In the research here, the data of students and teachers were observed during distance learning (PJJ) mathematics. The readiness level variables include ownership of electronic devices, availability of internet signals, costs, support from 
parents or people around, skills in accessing digital learning applications, learning places, teachers who are able to teach well, materials, teacher guidance, solutions if they encounter problems, never give up, and can understand distance learning material.

The questionnaire data obtained shows that students who do distance learning mathematics and male gender are $85.7 \%$ and female students are $14.3 \%$, this shows that students who enjoy mathematics are dominated by males. In contrast to Mathematics Teachers who are $0 \%$ Male and Mathematics Teachers who are $100 \%$ female, this shows that the profession as a teacher is dominated by women. This is in accordance with the research conducted by (Alrajeh \& Shindel, 2020) that female teachers are more able to support student involvement in mathematics classes. Research on gender differences and resilience affects $86.6 \%$ of students 'abilities in mathematical creative thinking and $13.4 \%$ is influenced by factors outside of gender and students' mathematical resilience (Dilla et al., 2018).

After the data is collected from the field, it is processed first, then descriptive statistics are carried out and analyzed.

\section{RESULTS AND DISCUSSION}

Fig. 1(a) shows the percentage of students' readiness to do distance learning, it can be seen that the percentage of students who are quite ready has the highest value of $35.7 \%$ followed by ready and very ready. Most of the students felt that they were quite ready to do distance learning. It should also be noted that there are students who are not very ready to implement distance learning, namely $7.1 \%$. These students need special attention from parents and teachers.

Fig. 1(b) shows the percentage of teacher readiness to do distance learning, it can be seen that the percentage of teachers ready to do distance learning has the highest value of $66.7 \%$ and the others are quite ready and very ready. So in this case the teacher can learn, adapt faster and be more prepared than students.

In Fig. 2(a) the percentage of device ownership (HP / Laptop / PC) of students when doing distance learning, it can be seen that the percentage of students with the highest score is $71.4 \%$. Most students have the tools to do distance learning.

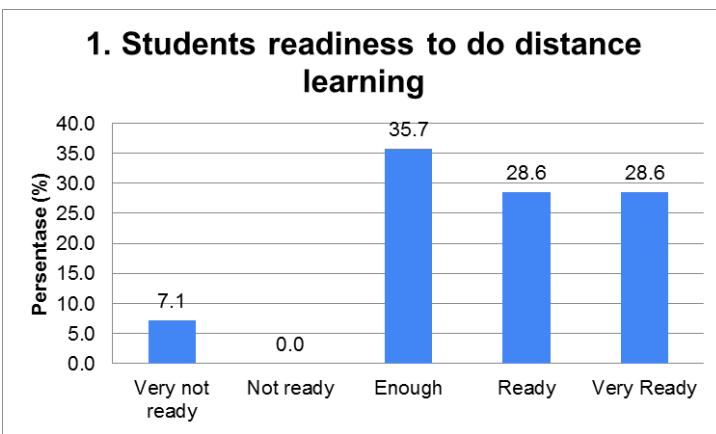

(a)

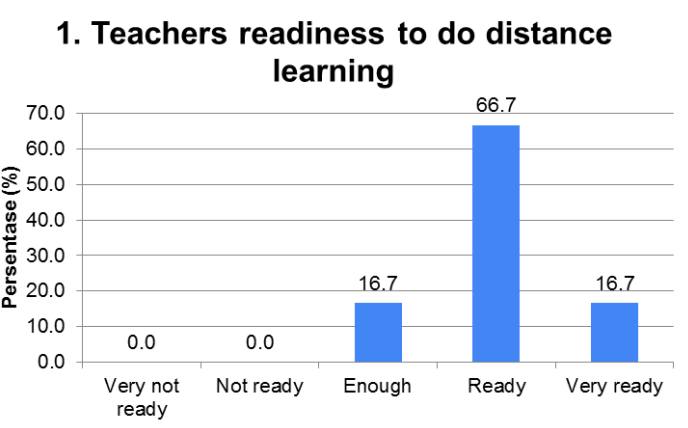

(b)

Fig.1 - Readiness (a) Students (b) Teacher doing distance learning 
Fig. 2 (b) shows the percentage of teacher ownership of equipment (HP / Laptop / PC) when doing distance learning, it can be seen that the percentage of teachers with the highest score of $50.0 \%$ is very owning and owning. Most of the teachers have the tools to do distance learning.

Internet signal is something that must be present when distance learning is carried out. Fig. 3(a) shows the percentage of signals students have during distance learning. The highest criterion is having that is 57.1\%. Likewise, Fig. 3(b) shows the percentage of signals that teachers have during distance learning. The highest criterion is to have that is $66.7 \%$.

The costs required during distance learning in the form of living costs, school facility fees, internet pulse costs and so on are shown in Fig. 4(a) for students. Most students feel they have the costs required during distance learning. There are also students who do not have a fee of $21.4 \%$, of course this needs to be the attention of the government and local residents so that they can continue to survive the difficulties in this pandemic era. Fig. 4(b) shows that most of the teachers have the funds needed to run distance learning. Financial support for mathematics learning has been carried out by (Chahine et al., 2020) by using robots to help students learn mathematics, and also to help teachers be more confident, can motivate and be more persistent to learn.

\section{Student's Device Ownership} (HP/Laptop/PC)

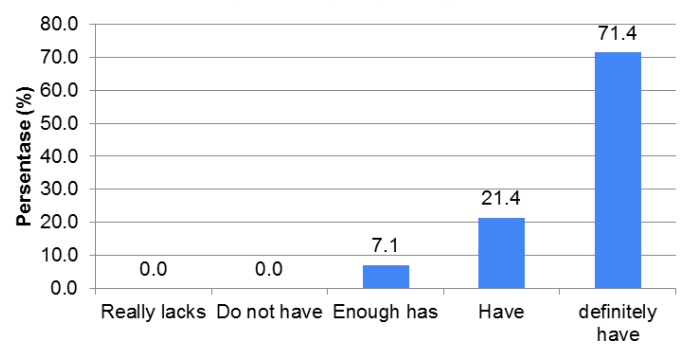

(a)
2. Teacher's Device Ownership (HP / Laptop / PC)

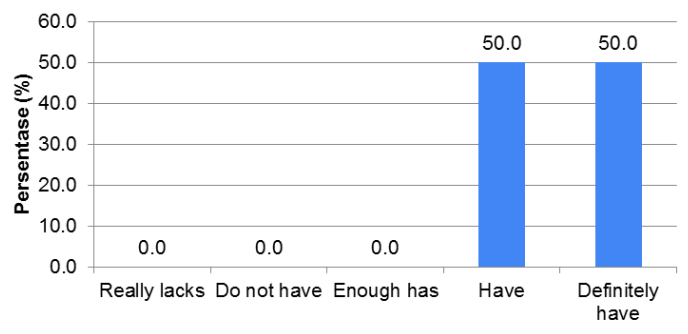

(b)

Fig. 2 - The ownership of devices (HP / Laptop / PC) (a) Students (b) Teachers.

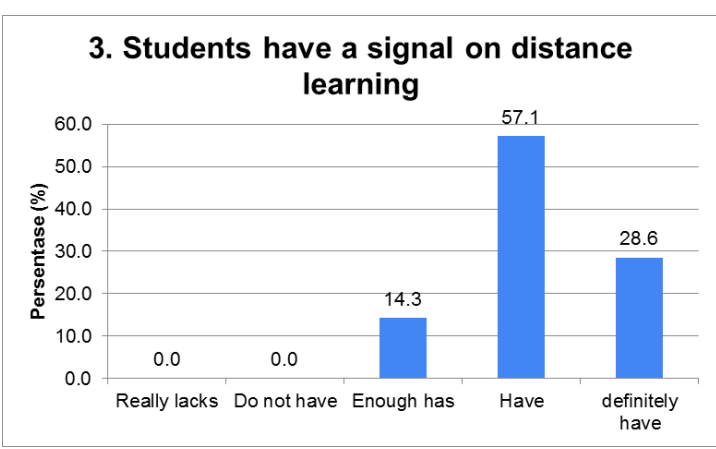

(a)
3. The teacher has a signal on distance learning

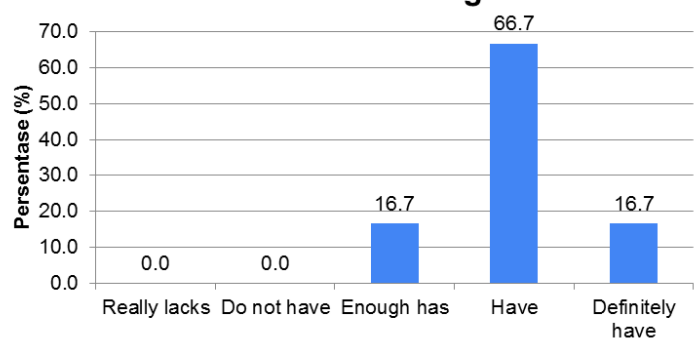

(b)

Fig. 3 - (a) Students (b) The teacher has a signal on the implementation of distance learning. 


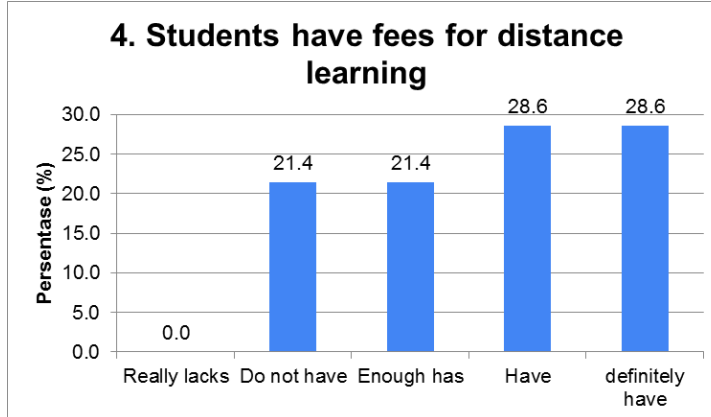

(a)

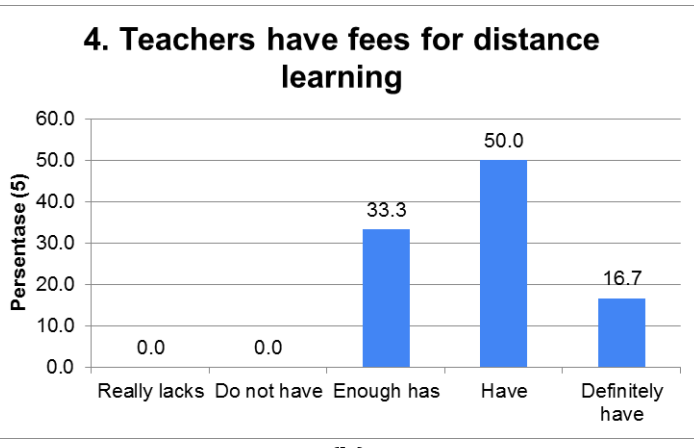

(b)

Fig. 4 - (a) Students (b) The teacher has costs for distance learning.

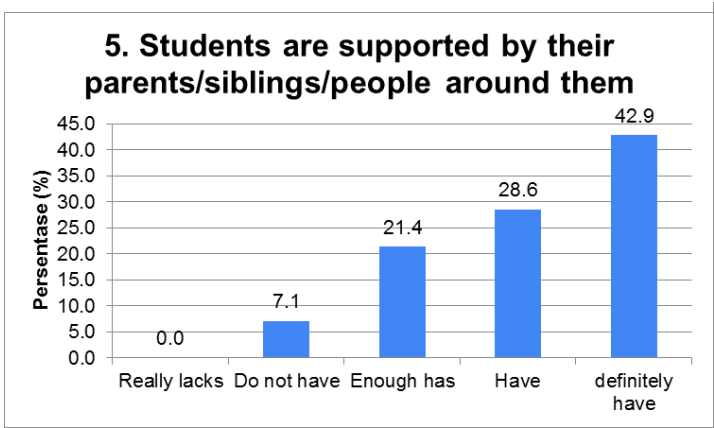

(a)

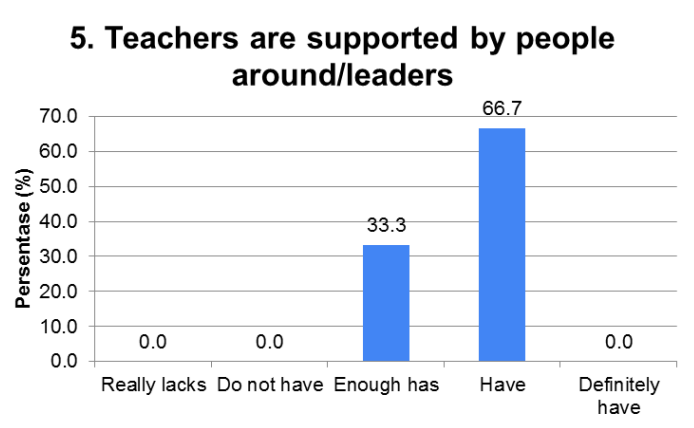

(b)

Fig. 5 - (a) Students (b) The teacher is supported by people around him during distance learning.

A learning process for students of course needs support from parents, older siblings, or people around them so that the results obtained are better. Fig.5(a) is the percentage of support students get during distance learning. The largest percentage is $42 \%$, namely students feel very supported in distance learning. Fig. 5 (b) shows the support felt by teachers during distance learning of $66.7 \%$ in the criteria of having support. Research on high level mathematics mastery has been conducted by (Tanudjaya \& Doorman, 2020) and one of the success factors is colleague support.

In Fig.6(a) is the percentage of the condition of students who have the skills to access distance learning applications very well at $42.9 \%$, then $21.4 \%$ good and $14.3 \%$ quite good. The percentage without the skills to access distance learning applications was 21.4\%. In Fig.6(b) is the percentage of teachers who have the skills to access applications with the largest percentage being $50 \%$ of teachers having it. One of the applications used today is the social media application which is used for communication between students and teachers in the field of mathematics lessons (Mulenga \& Marbàn, 2020). The use of social media such as Google Classroom (Huda et al., 2019), You Tube, WhatsApp, and Facebook has a positive influence on teaching and learning activities, especially in mathematics. 


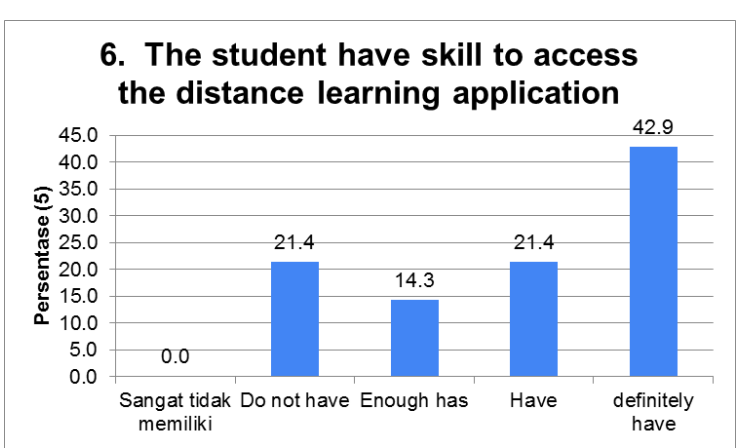

(a)

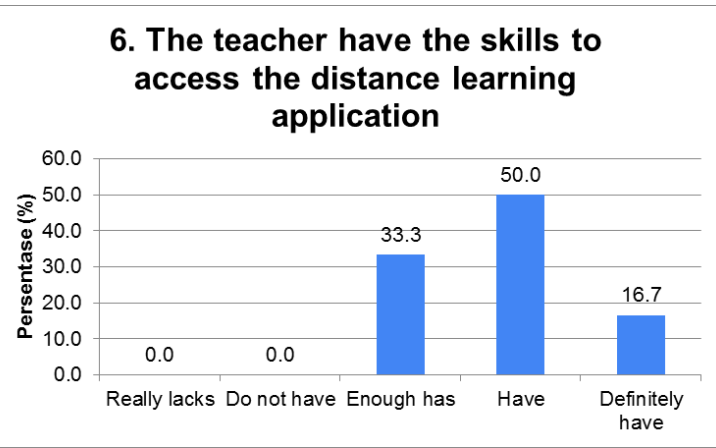

(b)

Fig. 6 - (a) Students (b) The teacher has skills to access the distance learning application.

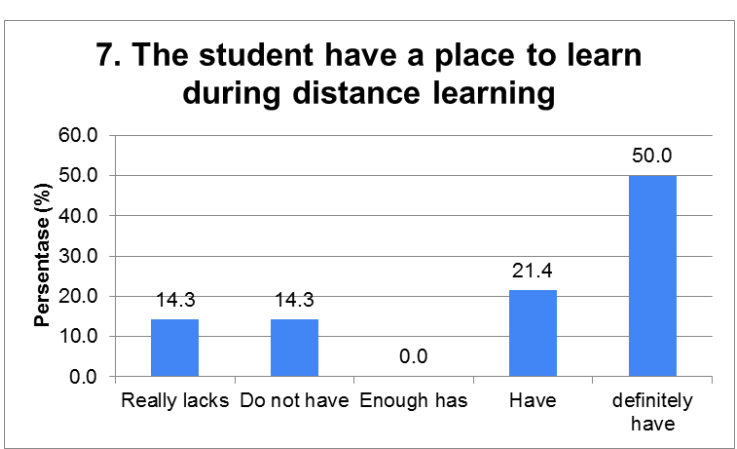

(a)

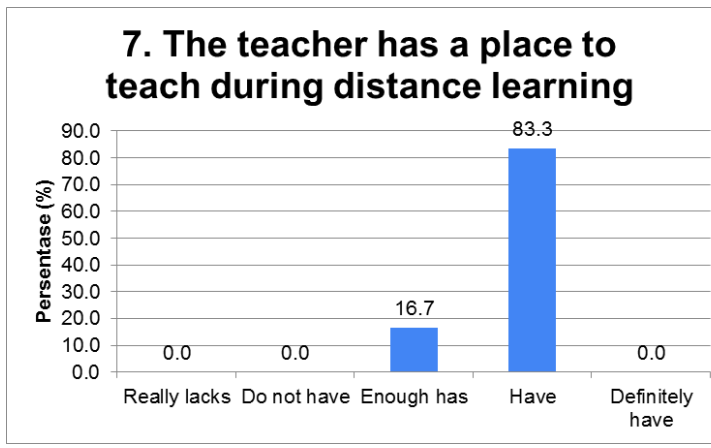

(b)

Fig. 7 - (a) Students (b) The teacher has a place to learn / teach during distance learning.

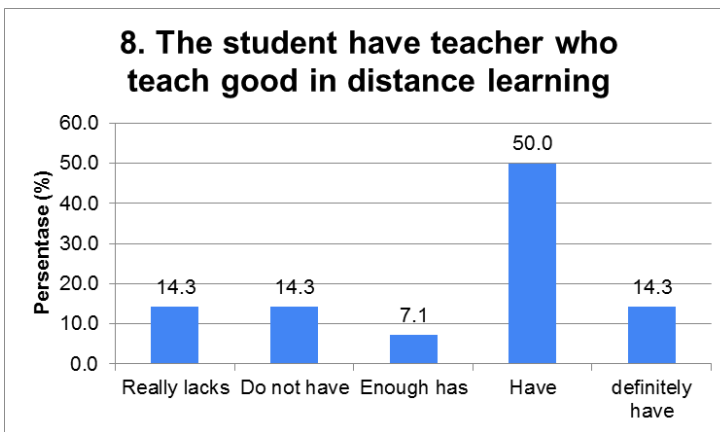

(a)

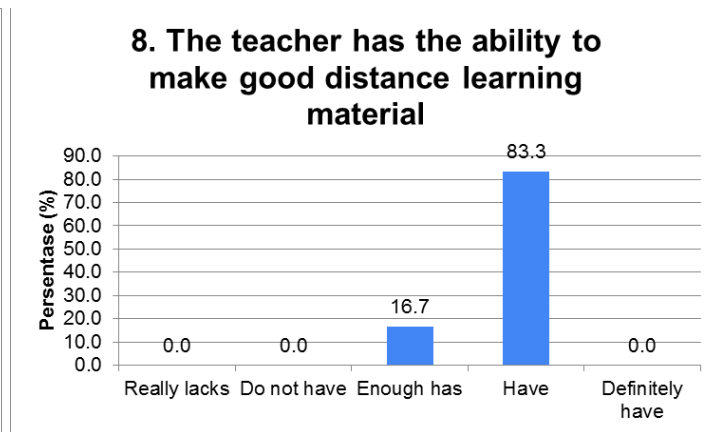

(b)

Fig. 8 - (a) Students have teachers who teach well (b) The teacher has the ability to make good distance learning material.

A comfortable place to study gives a sense of comfort in distance learning so that learning outcomes can improve learning performance. Therefore, here the researcher measures the level of place ownership that can be obtained for both students and teachers. Obtained for students where learning is owned by $71.4 \%$ but there are also those who really do not have and do not have a place to study, 28.6.3\% (Fig. 7(a)). Fig. 7(b) shows the condition of the percentage of teachers who have a place to teach, namely the largest $83.3 \%$. This is a relief to the world of education because teachers are expected to be able to optimally.

Fig. 8(a) and Fig. 8(b) show that students and teachers have good abilities in distance learning and the highest percentage results are $50 \%$ for students and $83.3 \%$ for teachers. 


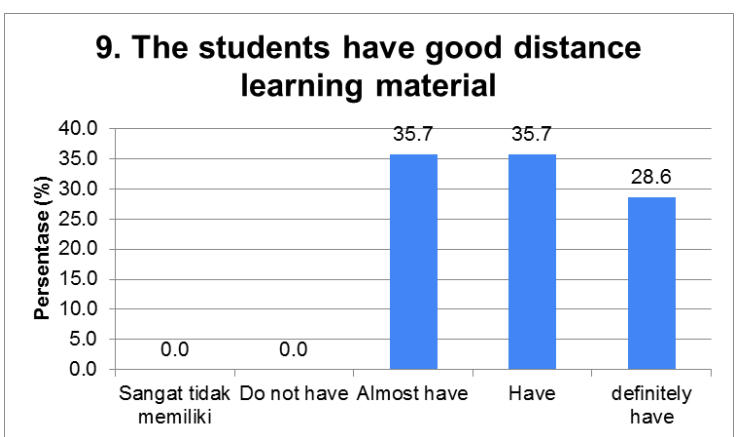

(a)

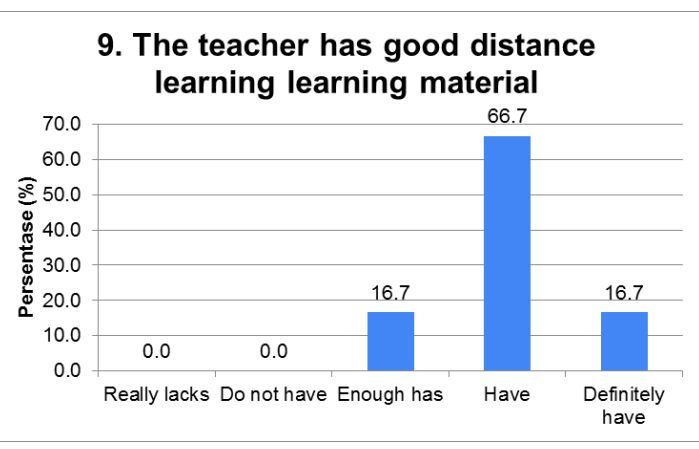

(b)

Fig. 9 - (a) Students (b) The teacher has good learning materials for distance learning.

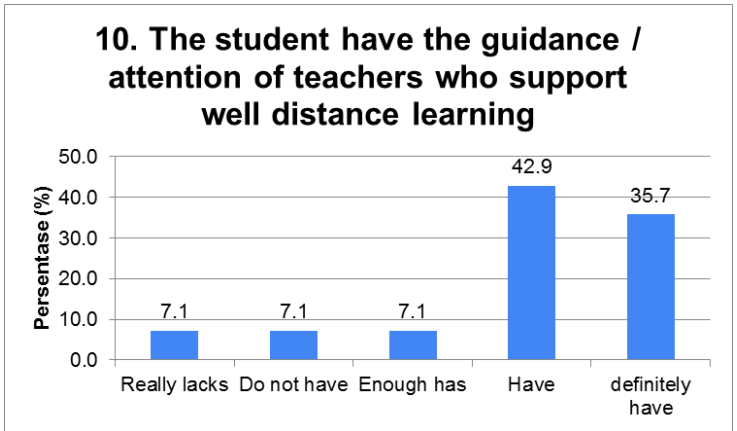

(a)

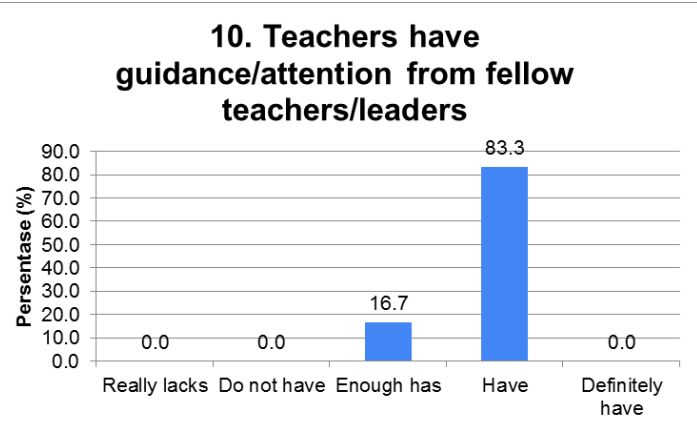

(b)

Fig. 10 - (a) Students have guidance / attention from teachers who support distance learning well, (b) Teachers have guidance / attention from fellow teachers / leaders.

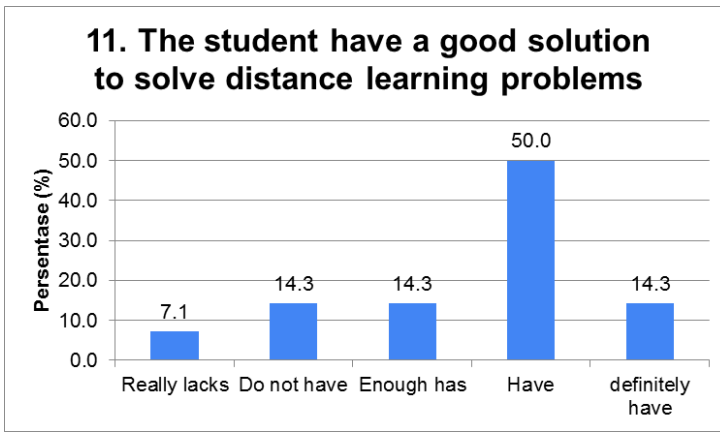

(a)

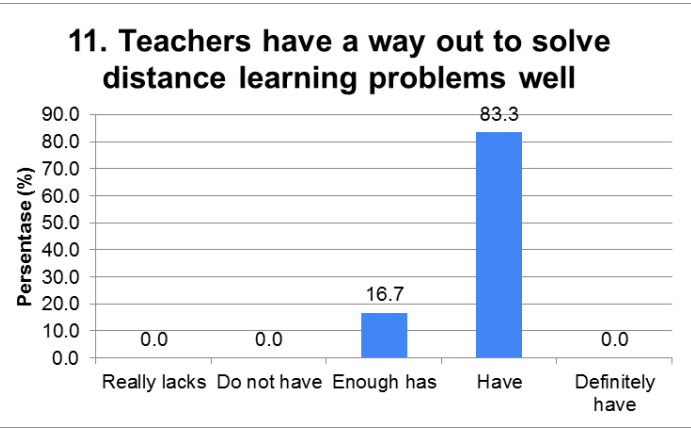

(b)

Fig. 11 - (a) Students (b) The teacher has a way out to solve the distance learning problem well.

Fig.9(a) and Fig. 9(b) show that students and teachers have good material in distance learning and the highest percentage results are $35.7 \%$ for students and $66.7 \%$ for teachers. Good digital material can increase students' independence in learning because students can use it repeatedly and indefinitely (Setiyani et al., 2020).

Fig. 10(a) and Fig. 10(b) show that students and teachers have guidance / attention that supports distance learning and the highest percentage results are $42.9 \%$ for students and $83.3 \%$ for teachers.

Fig. 11(a) and Fig.11(b) show that students and teachers have a way out to solve distance learning problems well and the highest percentage results are $50.0 \%$ for students and $83.3 \%$ for teachers. 
Fig. 12(a) and (b) show that students and teachers have an unyielding nature if they encounter difficulties with distance learning well and the highest percentage results are $35.7 \%$ for students and $50.0 \%$ for teachers. When students are faced with difficulties, students need to think creatively in order to solve their problems, one of which is by learning mathematics. After students practice solving problems, students will be more confident, and this will result in increased cognitive, affective, and self-concept abilities (Susilawati et al., 2020).

Fig. 13(a) and Fig. 13(b) show that students and teachers can understand the material on distance learning well and the highest percentage results are $35.7 \%$ for students and $50.0 \%$ for teachers.

Fig. 14(a) shows that students prefer the mixed type of learning face to face with learning at home with a percentage of $64 \%$ and Fig. 14(b) the teacher prefers the mixed type of learning face to face with learning at home by $50 \%$ or face to face physically $50 \%$. Distance learning and not meeting physically are very disliked by teachers. According to (Stacey \& Gerbic, 2008) a mixture of face-to-face and distance learning improves learning outcomes, especially those related to materials, research and practice. The same thing was expressed by (Graham \& Allen, 2011) (Güzer \& Caner, 2014). Blended learning is rapidly developing due to advances in technological innovation which can facilitate face-to-face meetings via online meetings.

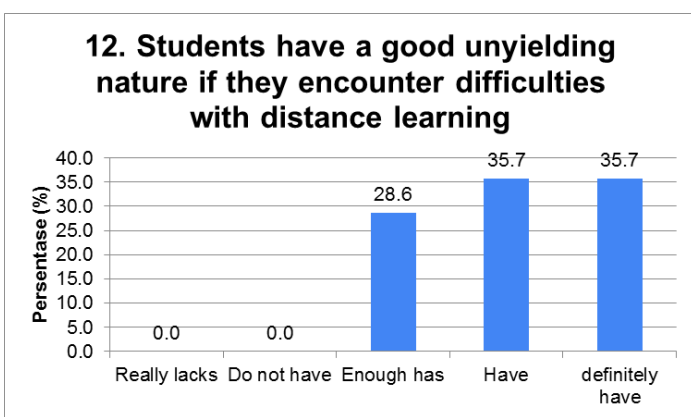

(a)

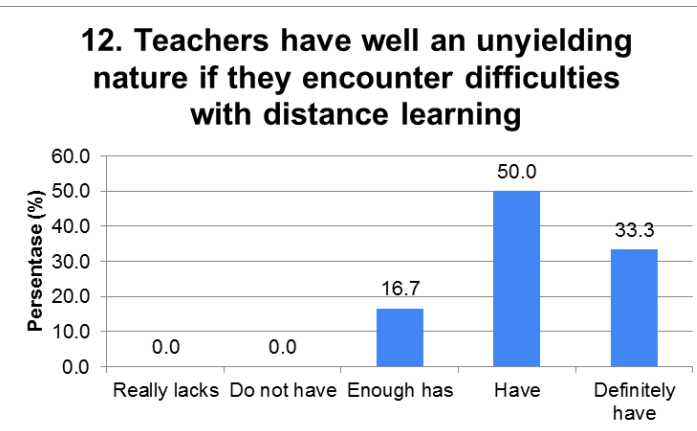

(b)

Fig. 12 - (a) Students (b) The teacher has an unyielding nature if he encounters difficulties with distance learning well.

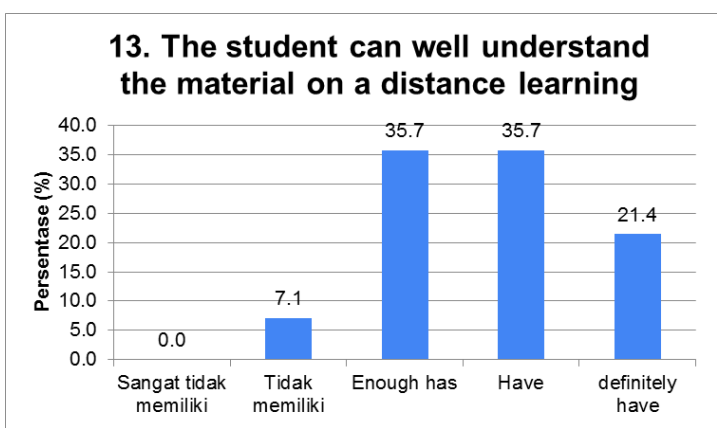

(a)

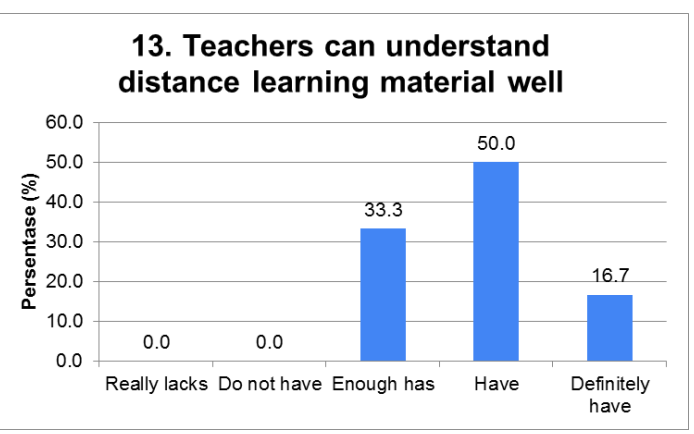

(b)

Fig. 13 - (a) Students (b) Teachers can understand the material in distance learning well 
14. Learning that the students like

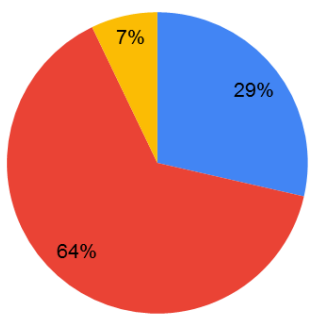

(a)
14. Learning that the Teachers like

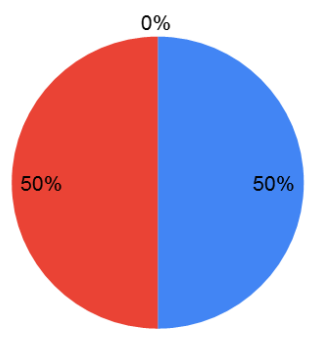

- Offline Learning mBlended learning $\square$ Online learning

Fig. 14. Learning preferences (a) Students (b) Teachers

(b)

\section{Discussion}

Most of the students felt that they were quite ready to do distance learning. It should also be noted that there are students who are not very ready to implement distance learning, namely 7.1\% (Fig. 1(a)). These students need special attention from parents and teachers. Most students (71.4\% in Fig. 2(a)) have the tools (HP / Laptop / PC) to do distance learning. To do distance learning the students that have signal is $57.1 \%$ in Fig. 3(a). It is need serious attention, because without good signal the distance learning cannot be done. For $21.4 \%$ (Fig. 4(a)) students did not have living cost so they have trouble to follow the distance learning. In Fig. 5(a) shows that $7.1 \%$ students did not have support from parents, older siblings, or people around them and the other have support. The condition of students who have the skills to access distance learning applications 78.6\% in Fig. 6(a) and the other $21.4 \%$ did not have skills to access distance learning applications. They must support to have skill using application for distance learning. The student who have comfort place to study is $71.4 \%$ and the other $28.6 \%$ did not have a comfort place. The students says they have good teachers, material, guidance/attention.

The teacher can learn, adapt faster and be more prepared than students to do distance learning (Fig. 1(b)). Most of the teachers have the tools to do distance learning (Fig. 2(b)). The teacher have 66.7\% signal internet in Fig. 3(b), it must be improved to support distance learning better. The teachers have the funds to run distance learning. The support from people around or leader were felt by teachers during distance learning (66.7\% in Fig. 5(b)). The teachers almost all can access applications distance learning. The teacher all have comfort place to teach. The Teacher has ability to make good distance learning, material and guidance/attention.

\section{CONCLUSION}

From the research results here it can be concluded that both students and teachers on average have distance learning readiness in the New Normal era. The 
percentage obtained from the results of questionnaires and interviews shows that most of them are in sufficient criteria to have very good readiness for facilities, materials, guidance, costs, support and so on. Students and teachers alike prefer to do mixed learning between distance learning and at home. From the interview results, it was found that teachers are required to master Information Technology more during this distance learning. Some things that the teacher dislikes are because during distance learning communication with students cannot go well, if students find it difficult to understand, the teacher cannot immediately explain and monitor the student's condition. Then the signal factor greatly affects the implementation of distance learning. In addition, the time needed to prepare distance learning material is longer. For students studying at home is more flexible and more relaxed, there is no need to go to school, the material can be repeated, but when the material is not understood, it is difficult to ask questions and constrained by the internet quota that is needed quite a lot. The weakness of distance learning is that it is constrained by internet signals, no emotional bonds, it is difficult to monitor students' abilities, and the higher credit costs.

\section{REFERENCES}

Alrajeh, T. S., \& Shindel, B. W. (2020). Student engagement and math teachers support. Journal on Mathematics Education, 11(2), 167-180. https://doi.org/10.22342/jme.11.2.10282.167-180

Chahine, I. C., Robinson, N., \& Mansion, K. (2020). Using robotics and engineering design inquiries to optimize mathematics learning for middle level teachers: A case study. Journal on Mathematics Education, 11(2), 319-332. https://doi.org/10.22342/jme.11.2.11099.319-332

Dilla, S. C., Hidayat, W., \& Rohaeti, E. E. (2018). Faktor Gender dan Resiliensi dalam Pencapaian Kemampuan Berpikir Kreatif Matematis Siswa SMA. Journal of Medives : Journal of Mathematics Education IKIP Veteran Semarang, 2(1), 129. https://doi.org/10.31331/medives.v2i1.553

Dziuban, C., Graham, C. R., Moskal, P. D., Norberg, A., \& Sicilia, N. (2018). Blended learning: the new normal and emerging technologies. International Journal of Educational Technology in Higher Education. https://doi.org/10.1186/s41239-017-0087-5

Gleim, D., \& Kuhl, D. (2017). Asynchronous and Synchronous Distance Learning in STEM Education, Using the Example of the Online Master Program Wind Energy Systems. AIP Conference Proceedings, 320016(1863), 1-4. https://doi.org/10.1063/1.4992497

Graham, C. R., \& Allen, S. (2011). Blended Learning Environments. In Encyclopedia of Distance Learning. https://doi.org/10.4018/978-1-59140-555-9.ch024

Güzer, B., \& Caner, H. (2014). The Past, Present and Future of Blended Learning: An in Depth Analysis of Literature. Procedia - Social and Behavioral Sciences. 
https://doi.org/10.1016/j.sbspro.2014.01.992

Han, S., Capraro, R., \& Capraro, M. M. (2014). How Science, Technology, Engineering, and Mathematics (STEM)Project-based Learning (PBL) affects high, middle, and low achievers differently: The impact of student factors on achievement. International Journal of Science and Mathematics Education. https://doi.org/10.1007/s10763-014-9526-0

Huda, S., Firmansyah, M., Rinaldi, A., Suherman, S., Sugiharta, I., Astuti, D. W., Fatimah, O., \& Prasetiyo, A. E. (2019). Understanding of Mathematical Concepts in the Linear Equation with Two Variables: Impact of E-Learning and Blended Learning Using Google Classroom. Al-Jabar: Jurnal Pendidikan Matematika, 10(2), 261-270. https://doi.org/10.24042/ajpm.v10i2.5303

Idaho Digital Learning. (2014). 6 Models of Blended Learning. 6 Models of Blended Learning.

Lijie, Z., Zongzhao, M., \& Ying, Z. (2020). The Influence of Mathematics Attitude on Academic Achievement: Intermediary Role of Mathematics Learning Engagement. Jurnal Cendekia : Jurnal Pendidikan Matematika, 4(2), 460-467. https://doi.org/10.31004/cendekia.v4i2.253

Miles, M. B., \& Huberman, A. M. (2014). Qualitative Data Analysis. In SAGE Publications (Vol. 1304).

Mulenga, E. M., \& Marbàn, J. M. (2020). Social media usage among pre-service secondary mathematics teachers in Zambia. JRAMathEdu (Journal of Research and Advances in Mathematics Education), 5(2), 130-147. https://doi.org/10.23917/jramathedu.v5i2.9920

Setiyani, Putri, D. P., Ferdianto, F., \& Fauji, S. H. (2020). Designing a digital teaching module based on mathematical communication in relation and function. Journal on Mathematics Education, 11(2), 223-236. https://doi.org/10.22342/jme.11.2.7320.223-236

Silverman, J., \& Hoyos, V. (2018). Distance Learning, E-Learning and Blended Learning in Mathematics Education International Trends in Research (ICME-13 Mo). Springer International Publishing AG. https://doi.org/10.1007/978-3319-90790-1 Library

Stacey, E., \& Gerbic, P. (2008). Success factors for blended learning. ASCILITE 2008 - The Australasian Society for Computers in Learning in Tertiary Education.

Susilawati, S., Pujiastuti, H., \& Sukirwan, S. (2020). Analisis Kemampuan Berpikir Kreatif Matematis Ditinjau Dari Self-Concept Matematis Siswa. Jurnal Cendekia: Jurnal Pendidikan Matematika, 4(2), 512-525. https://doi.org/10.31004/cendekia.v4i2.244

Tanudjaya, C. P., \& Doorman, M. (2020). Examining higher order thinking in Indonesian lower secondary mathematics classrooms. Journal on Mathematics Education, 11(2), 277-300. https://doi.org/10.22342/jme.11.2.11000.277300 